\title{
The Role of Heparin-Binding Growth-Associated Molecule (HB-GAM) in the Postsynaptic Induction in Cultured Muscle Cells
}

\author{
H. Benjamin Peng, ${ }^{1}$ A. Afshan Ali, ${ }^{1}$ Zhengshan Dai, ${ }^{1}$ David F. Daggett, ${ }^{1}$ Erkki Raulo, ${ }^{2}$ and Heikki Rauvala ${ }^{2}$ \\ 'Department of Cell Biology and Anatomy and Curriculum in Neurobiology, University of North Carolina, Chapel Hill, \\ North Carolina 27599 and ${ }^{2}$ Institute of Biotechnology, University of Helsinki, Helsinki, Finland
}

The heparan sulfate proteoglycan (HSPGs) is a components of the extracellular matrix of skeletal muscle that is concentrated at the neuromuscular junction (NMJ). Recent studies have suggested that HSPG, together with its bound peptide growth factors, plays important roles in autocrine or paracrine types of regulation of cell growth and differentiation. Heparin-binding growth-associated molecule (HB-GAM; also known as pleiotrophin, or p18) is a newly discovered HSPG-bound factor that is expressed at high levels in the developing CNS and PNS. In this study, we examined the role of this factor in NMJ development by examining its relationship to the formation of ACh receptor (AChR) clusters. Using an antibody against recombinant rat brain HB-GAM, we found that this protein is present prominently on the surface of cultured Xenopus myotomal muscle cells by immunocytochemistry. It is associated with HSPGs as evidenced by the fact that heparin and heparinase treatment greatly diminished the antibody labeling. HB-GAM is concentrated at preexisting AChR hot spots as well as at those induced by polystyrene beads. In addition, this molecule is also concentrated at AChR clusters induced by spinal cord neurons in nerve-muscle cocultures. To assess its function in synaptic induction, we applied recombinant HB-GAM-coated beads to cultured muscle cells to effect its focal presentation. Over $70 \%$ of these beads induced the formation of AChR clusters as shown by fluorescent $\alpha$-bungarotoxin labeling. Furthermore, bath application of HB-GAM inhibited the nerve-induced formation of AChR clusters. Thus, HB-GAM is an endogenous muscle-derived factor that may be a component of the molecular mechanism in postsynaptic induction.

[Key words: heparin-binding growth-associated molecule (HB-GAM), pleiotrophin, neuromuscular junction (NMJ), synaptogenesis, Xenopus, heparan sulfate proteoglycan (HSPG)]

\footnotetext{
Received Aug. 9, 1994; revised Nov. 2, 1994; accepted Nov. 8, 1994.

This work was supported by NIH Grant NS23583 and the Muscular Dystrophy Association. We thank Dr. John Anderson for providing the HSPG antibody, Dr. Howard Fried for the gift of A6 cells, Rhone-Poulenc Rorer for the gift of tyrphostins, and Synergen for recombinant bFGF. We also thank Drs. J.-S. Huang and M.-D. Kuo for samples of HB-GAM isolated from bovine brain at the early stage of this study.

Correspondence should be addressed to Dr. H. Benjamin Peng, Department of Cell Biology and Anatomy, University of North Carolina, CB\#7090, 108 Taylor Hall, Chapel Hill, NC 27599.

Copyright (C) 1995 Society for Neuroscience $0270-6474 / 95 / 153027-12 \$ 05.00 / 0$
}

Synaptic development at the neuromuscular junction (NMJ) is induced by the contact between the growth cone of the motor axon and the skeletal muscle cell. This contact presents a highly localized signal to both the nerve and the muscle to initiate the formation of pre- and postsynaptic specializations that are precisely registered in space (Hall and Sanes, 1993). Clustering of nicotinic ACh receptors (AChRs) is the hallmark of vertebrate postsynaptic development. In response to innervation, AChRs are clustered discretely at the nerve-muscle (N-M) contact. This spatial restriction in $\mathrm{AChR}$ clustering necessitates a signaling system that has a limited diffusion radius.

Previous studies have shown that the heparan-sulfate proteoglycan (HSPG) is an important component of the extracellular matrix (ECM) of skeletal muscle (Anderson and Fambrough, 1983; Anderson et al., 1984; Bayne et al., 1984; Anderson, 1986; Swenarchuk et al., 1990). They are concentrated at the $\mathrm{NMJ}$ in vivo and in vitro as well as at aneural $\mathrm{ACh}$ receptor (AChR) clusters ("hot spots") in cultured muscle cells. Recent studies have demonstrated that this proteoglycan can harbor heparin-binding growth factors (HBGFs) at the cell surface (Risau and Ekblom, 1986; Rifkin and Moscatelli, 1989; Klagsbrun and Baird, 1991; Bernfield et al., 1992; Salmivirta et al., 1992; Higashiyama et al., 1993). These factors can be released or presented to their receptors during cell-cell interaction to signal cell growth or differentiation (Saksela and Rifkin, 1990; Brunner et al., 1991). An important feature of this class of molecules is that they are spatially restricted when bound to HSPG (Flaumenhaft et al., 1990). The role of HBGFs in NMJ development is suggested by our recent studies that local presentation of basic fibroblast growth factor (bFGF), which binds to HSPG with high affinity, via latex beads stimulates the formation of AChR clusters in cultured Xenopus muscle cells (Peng et al., 1991a). However, immunocytochemical study has not revealed an abundance of bFGF at the surface of Xenopus skeletal muscle cells, nor at the NMJ (Baker et al., 1992). In addition, the primary sequence of this factor lacks a classical signal peptide (Esch et al., 1985; Mignatti et al., 1992). Thus, it is not clear how this molecule can be externalized to effect synaptic induction.

To further explore the role of HSPG and its associated molecules in NMJ development, we examined the expression and function of a newly discovered HBGF, the heparin-binding growth-associated molecule (HB-GAM; also known as pleiotrophin, or p18). As its name implies, it binds to heparin and HSPG with high affinity (Rauvala, 1989; Li et al., 1990; Merenmies and Rauvala, 1990; Hampton et al., 1992; Raulo et al., 1992). The cDNA for this factor encodes a protein with 136 amino acids with an $\mathrm{N}$-terminal signal sequence. The amino acid se- 
quence of this molecule is highly conserved across species. Two features of this sequence are particularly striking. First, it shows a high content of basic amino acids which are clustered at its $\mathrm{N}$ - and C-terminals. Second, it possesses 10 cysteines, all of which have been shown to form disulfide bonds. These features, as well as the overall sequence, are shared by members of a family of retinoid acid-induced heparin-binding factors, such as midkinc (Kadomatsu et al., 1988; Matsubara ct al., 1990; Kretschmer et al., 1991). Previous studies have shown the expression of HB-GAM in a variety of tissues, including brain, skeletal muscle, and kidney, in a developmentally regulated manner (Rauvala, 1989; Li et al., 1990; Hampton et al., 1992). While its expression is downregulated in other tissues during development, it persists in the brain beyond neonatal stages (Rauvala, 1989; Li et al., 1990). In vitro assays have shown that it exhibits neurite-promoting activity when applied on the substratum (Rauvala, 1989; Kuo et al., 1990; Kretschmer et al., 1991; Hampton et al., 1992) and may also be a mitogen to certain fibroblast cell lines (Li et al., 1990; Fang et al., 1992).

In this study, we examined the distribution of HB-GAM in cultured muscle cells and its relationship to NMJ development. Here we report that HB-GAM is present prominently at the surface of cultured Xenopus myotomal muscle cells, where it is associated with HSPG. It becomes concentrated at $\Lambda \mathrm{ChR}$ clusters induced by innervation as well as by other stimuli. Local presentation of this factor by beads induces the formation of AChR clusters in these muscle cells. On the other hand, bath application interferes with the nerve-induced AChR clustering. These data suggest that HB-GAM is an endogenous musclederived growth factor that may play an important role in the signal transduction process leading to postsynaptic differentiation at the developing NMJ.

\section{Materials and Methods}

Production of recombinant proteins and antibodies. Recombinant HBGAM was produced with the aid of a baculovirus vector and the secreted protein was purified to apparent homogeneity from the culture medium of the SF9 cells as described previously (Raulo et al., 1992). For comparison, amphoterin, another heparin-binding factor was also used in this study (Rauvala et al., 1988; Merenmies et al., 1991). Recombinant amphoterin was also expressed in SF9 cells using a baculovirus vector and purified in a similar manner as HB-GAM (Parkkinen et al., 1993). Immune sera against the purified recombinant HB-GAM were produced in rabbits as described previously (Raulo et al., 1992). IgG was isolated from the immune sera using protein A-Sepharose (Pharmacia, Sweden) as recommended by the manufacturer. For affinity purification of the antibodies, $5 \mathrm{mg}$ of recombinant HB-GAM was coupled to a $1 \mathrm{ml}$ cynogen bromide-activated Sepharose 4B column (Pharmacia, Sweden). Antibodies bound to the affinity column from the immune sera in the presence of $0.6 \mathrm{M} \mathrm{NaCl}$ were purified as described previously (Rauvala et al., 1988).

Cell cultures. Muscle cells were isolated from Xenopus embryos according to a previously published method (Peng et al., 1991b). They were plated on $35 \mathrm{~mm}$ tissue culture dishes for Western blot experiments or on $12 \mathrm{~mm}$ coverglass circles for immunofluorescence experiments. The cultures were maintained in Steinberg's solution $[60 \mathrm{mM}$ $\mathrm{NaCl}, 0.7 \mathrm{~mm} \mathrm{KCl}, 0.4 \mathrm{~mm} \mathrm{Ca}\left(\mathrm{NO}_{3}\right)_{2}, 0.8 \mathrm{~mm} \mathrm{MgSO}_{4}, 10 \mathrm{~mm}$ HEPES, $\mathrm{pH} 7,4$ ] supplemented with $10 \% \mathrm{~L}-15$ medium, $1 \%$ fetal bovine serum, and $100 \mu \mathrm{g} / \mathrm{ml}$ gentamycin at $22^{\circ} \mathrm{C}$ (Peng et al., 1991b). To study NMJs in culture, neural tubes from Xenopus embryos were separated from the Inyotomes after collagenase treatment $(1 \mathrm{mg} / \mathrm{ml}$ for $30 \mathrm{~min})$ and dissociated into single neurons in $\mathrm{Ca}^{2+}, \mathrm{Mg}^{2+}$-free Steinberg's solution. They were then plated onto $3-4 \mathrm{~d}$ muscle cultures. A ratio of five neural tubes per muscle culture was found to be satisfactory in the establishment of easily identifiable nerve-muscle pairs. Functional NMJs can be observed within the first day of $\mathrm{N}-\mathrm{M}$ coculture.

Xenopus kidney epithelial cell line A6 (Rafferty, 1969) was obtained from Dr. Howard Fried (Department of Biochemistry, University of
North Carolina at Chapel Hill) and from American Type Culture Collection (Rockville, MD). It was cultured in Waymouth's culture medium with $10 \%$ fetal calf serum and karamycin/gentamycin at $22^{\circ} \mathrm{C}$ in tissue culture flasks.

Western blots. Muscle and epithelial cultures were washed three times with phosphate-buffered saline (PBS) and then lysed by the addition of lysis buffer ( $25 \mathrm{~mm}$ Tris-HCl, pH 7.4, $50 \mathrm{~mm} \mathrm{NaCl}, 0.5 \%$ Na-deoxycholate, $2 \% \mathrm{NP}-40,0.2 \% \mathrm{SDS}, 10 \mu \mathrm{g} / \mathrm{ml}$ aprotinin, $0.5 \mu \mathrm{g} / \mathrm{ml}$ leupeptin, $0.7 \mu \mathrm{g} / \mathrm{ml}$ pepstatin, and $0.5 \mathrm{~mm}$ PMSF). Cells were scraped off from the dishes and briefly homogenized with a Brinkmann (Westbury, NY) PT-1200 Polytron-type homogenizer. The protein concentration of the lysate was determined with the Bio-Rad (Richmond, CA) method using a kit supplied by the company. Samples were prepared according to Laemmli (Laemmli, 1970) and were resolved on a 12\% SDS-polyacrylamide gel. Proteins were transferred to nitrocellulose membrane (BioRad) with a semi-dry electrophoretic transfer device (Pharmacia-LKB, Piscataway, NJ). The membrane was treated with the blocking buffer [10 mm Tris, pH 8, $50 \mathrm{~mm} \mathrm{NaCl}, 0.05 \%$ Tween-20, 2\% BSA, and $1 \%$ cold fish gelatin (Sigma, St. Louis, MO)] for $1 \mathrm{hr}$ and then incubated with antibody against $\mathrm{HB}-\mathrm{GAM}$ at $2 \mu \mathrm{g} / \mathrm{ml}$ reconstituted in Tris buffer (same as the blocking buffer except for the omission of BSA) at room temperature. After washing with the Tris buffer, the membrane was incubated with HRP-conjugated secondary antibody (Sigma) and the protein bands were visualized with the enhanced chemiluminescence (ECL) method with a kit supplied by Du Pont (Boston, MA).

Immunofluorescent labeling. Cultures were immunolabeled with antibody against HB-GAM in the living state. Cultures were incubated with antibodies reconstituted with culture medium to a concentration of $50-66 \mathrm{nM}$ for $45 \mathrm{~min}$, rinsed and labeled with a FITC or rhodamineconjugated goat anti-rabbit secondary antibody (Organon Teknika, Durham, NC) for $30 \mathrm{~min}$. The labeling was carried out either at room temperature or at $4^{\circ} \mathrm{C}$. They were either observed alive or fixed with $95 \%$ ethanol at $-20^{\circ} \mathrm{C}$ followed by mounting in a polyvinyl alcohol based mounting medium which contained $5 \% n$-propyl gallate as antifading agent (Giloh and Sedat, 1982). To visualize AChK clusters, muscle cultures were also double labeled with tetramethylrhodamine-conjugated $\alpha$-bungarotoxin (R-BTX) at a concentration of $0.3 \mu \mathrm{M}$ for 30 min. As a control, we labeled cultures with the secondary antibody alone without the primary antibody. These cultures were completely devoid of fluorescent staining. The competition between HB-GAM and bFGF in binding to HSPG was studied by treating cultures with recombinant bFGF (Synergen, Boulder, CO) at a concentration of $1 \mu \mathrm{g} / \mathrm{ml}$ for $30 \mathrm{~min}$, followed by labcling with a mouse monoclonal antibody against this protein (Type I from UBI, Lake Placid, NY) and the rabbit polyclonal HB-GAM antibody to visualize these two proteins at the cell surface.

A monoclonal antibody against heparan sulfate (HepSS-1 from Seikagaku) was used to detect the HSPG on the surface of muscle cells (Kure and Yoshie, 1986). It was used at 1:200 dilution to label live cultures. The staining pattern of this antibody was similar to that obtained through the use of $\mathrm{mAb} 2 \mathrm{AC} 2$, an anti-HSPG core protein antibody kindly provided by Dr. M. J. Anderson (University of Calgary).

Heparin and heparinase treatment. Low molecular-weight heparin (Sigma, M.W. 40006000 ) was used to displace HB-GAM from the cell surface. Cultures were treated with heparin at a concentration of 100 $500 \mu \mathrm{g} / \mathrm{ml}$ for $1 \mathrm{hr}$, followed by immunolabeling. To remove the HSPG from the cell surface, we treated cultures at room temperature with heparinase (Type I from Sigma) at a concentration of $50 \mathrm{U} / \mathrm{ml}$ for $4 \mathrm{hr}$ in culture medium for immunolabeling or in PBS for Western blot. This was followed by antibody labeling. For Western blot, the conditioned medium after heparinase treatment was collected and centrifuged at $13,000 \mathrm{rpm}$. The supernatant was freeze dried and desalted with spin columns (Bio-Rad) and prepared for PAGE and Western blots. After the heparinase treatment, the cells were also harvested by scraping them off the substrate, pelleted by centrifugation, washed and lysed with lysis buffer, and prepared for PAGE.

Induction of AChR clustering by beads coated with HB-GAM. Ten micrometer polystyrene latex beads (Polysciences) were washed with 95\% ethanol, rinsed, and incubated with recombinant HB-GAM in the range of $1-100 \mu \mathrm{g} / \mathrm{ml}$ in PBS for 1-3 hr. The beads were then washed with PBS and the unoccupied area on the bead surface was blocked with culture medium containing $1 \%$ fetal bovine serum or with PBS containing $1 \mathrm{mg} / \mathrm{ml} \mathrm{BSA}$. The beads were then applied to muscle cultures. After an overnight incubation, the cultures were labeled with R-BTX or HB-GAM antibody. To visualize the adsorption of HB-GAM 
on beads, we labeled the beads with anti-HB-GAM antibody followed by fluorescently conjugated secondary antibody. The size of bead-induced clusters was quantified by digital video imaging methods. The images were acquired with a SIT camera connected to a computer running IMAGE-1 image processing software (Universal Imaging, Chester, PA). The clusters were then individually quantified with the analysis program in the same software package.

Suramin and tyrphostin application. Suramin was obtained from FBA Pharmaceuticals (New York, NY). Cultures were treated with this drug at a concentration ranging from $1-100 \mu \mathrm{M}$ for $15 \mathrm{~min}$ before the addition of HB-GAM-coated beads. The drug concentration was maintained through the duration of the $24 \mathrm{hr}$ bead-muscle coculture. Tyrphostins, RG-50864 (active) and RG-50862 (inactive), were kind gifts of Rhone-Poulenc Rorer Central Research (Horsham, PA). They were dissolved in dimethyl sulfoxide (DMSO) to make a $40 \mathrm{~mm}$ stock that was stored at $-80^{\circ} \mathrm{C}$. Cultures were pretreated with tyrphostin in the range of $20-100 \mu \mathrm{M}$ for $3 \mathrm{hr}$ before the beads were added. Thereafter, they were maintained in the tyrphostin-containing medium for 24-48 $\mathrm{hr}$ before R-BTX labeling.

Bath application of $H B-G A M$ and amphoterin. Stock solution of recombinant HB-GAM or amphoterin was dialyzed against Steinberg solution through a membrane with $3000 \mathrm{M}$.W. cutoff. The dialyzed solution was then diluted with culture medium. To each muscle culture on $12 \mathrm{~mm}$ round coverglass circle placed in an 8 well dish whose bottom was lined with parafilm, $50 \mu \mathrm{l}$ of medium with HB-GAM or amphoterin was added. Neurons, suspended in minimum amount of medium after dissociation, were seeded into each culture. The 8 well dish was then sealed, placed in a moisture chamber and incubated at $22^{\circ} \mathrm{C}$ for $18-24 \mathrm{hr}$. The cultures were then labeled with R-BTX and examined live under a fluorescence microscope. The presence of $\mathrm{AChR}$ clusters along each unambiguous N-M contact visualized with phasecontrast optics was scored. The percentage of contacts that were positive in AChR clusters was calculated for each sample.

Immunofluorescent labeling of embryos. The dorsal parts of embryos at stage $22-32$, containing the myotomes, the neural tube and the notochord, were excised. They were briefly treated with $\mathrm{Ca}^{2+}, \mathrm{Mg}^{2+}$-free Steinberg's solution to remove the skin. The pieces were then labeled in the living state with HB-GAM antibody followed by rhodamineconjugated secondary antibody. In some experiments, pieces were double labeled with FITC-conjugated $\alpha$-bungarotoxin. The embryo pieces, either in the living state or after fixation with $95 \%$ ethanol at $-20^{\circ} \mathrm{C}$, were then mounted by sandwiching them between a slide and a coverslip, which caused their flattening. This made the myotomes clearly visible by their characteristic segmented appearance. The edge of the coverslip was sealed with nail enamel, and the specimen was observed under a fluorescence microscope.

\section{Results}

\section{Immunoblot analysis of HB-GAM in Xenopus cells}

To examine the presence of HB-GAM in Xenopus muscle cells, we first conducted Western blot analyses on these cells. As shown in Figure 1 (lane 1), the polyclonal antibody made against baculovirus-derived recombinant HB-GAM recognized the recombinant protein as a major $18 \mathrm{kDa}$ band. The minor band at a slightly lower molecular mass in this lane is probably a proteolytic breakdown product. In contrast, the same amount of recombinant bFGF, which also has a molecular mass of $18 \mathrm{kDa}$, was not recognized by this antibody (Fig. 1, lane 2). When the lysate of cultured Xenopus muscle cells was electrophoresed, blotted, and probed with this antibody, a band at $18 \mathrm{kDa}$ was clearly seen (Fig. 1, lane 4). In this and other muscle samples, a nonspecific band at $100 \mathrm{kDa}$ was also observed. This band is due to the yolk protein that is present in large amount inside these cells in the form of yolk platelets. Since the yolk protein is very sticky, it tends to adsorb antibodies in a nonspecific manner, resulting in nonspecific bands in Western blots (Evans and Kay, 1991). A previous study has shown that HB-GAM is also found in embryonic rat kidney (Merenmies and Rauvala, 1990). Thus, we also studied the expression of this protein in the A6 cell line derived from Xenopus kidney epithelial cells

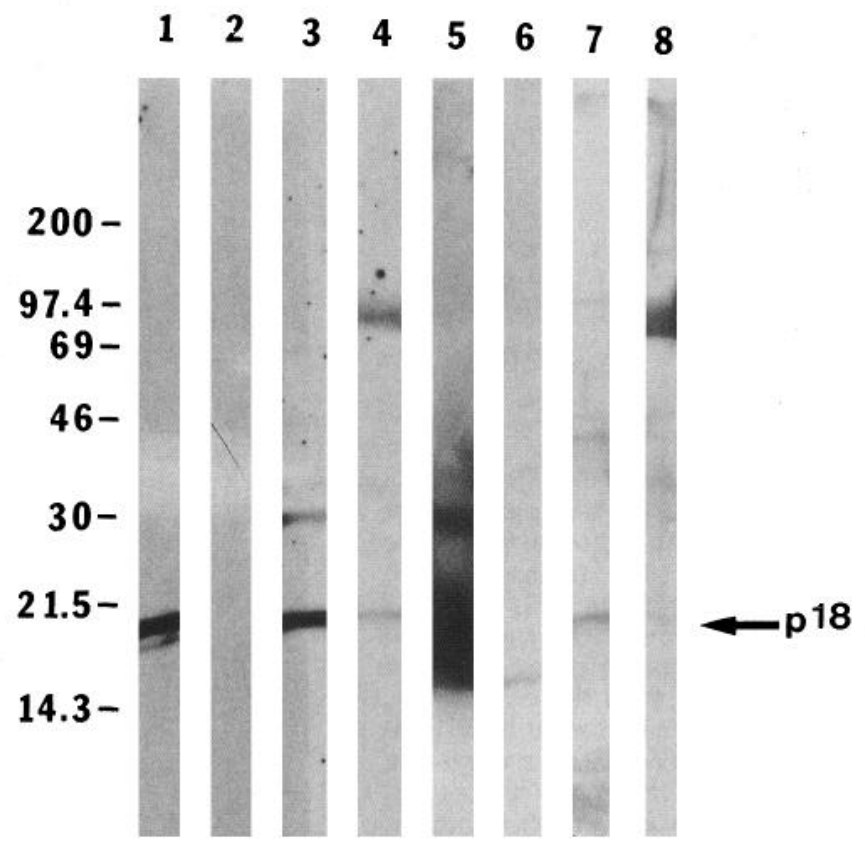

Figure 1. Western blot of HB-GAM. Lane 1, Recombinant HB-GAM, $0.25 \mu \mathrm{g}$; lane 2 , recombinant bFGF, $0.25 \mu \mathrm{g}$; lane 3 , A6 cell lysate; lane 4, muscle cell lysate; lane 5, conditioned medium from A6 cultures after heparinase treatment; lane 6 , A6 cell lysate after heparinase treatment; lane 7 , conditioned medium from muscle cultures after heparinase treatment; lane 8, muscle cell lysate after heparinase treatment. In lanes $1,3,4,7$, a band at $18 \mathrm{kDa}(p 18)$ corresponding to HB-GAM can be seen. The $100 \mathrm{kDa}$ band seen in lanes 4 and 8 is due to yolk protein in these muscle cells, which is very sticky and tends to give nonspecific antibody binding. The $30 \mathrm{kDa}$ minor band in lanes 3 and 5 is routinely seen in the A6 preparation. Since it is eluted from the cell surface after heparinase treatment (lane 5) and is no longer seen in the cell lysate (lane 6), this protein is probably also bound to the HSPG. It may represent another protein that shares structural homology with HB-GAM. The broadening of the bands in lane 5 is due to protein overloading. Affinity-purified HB-GAM antibody was used in this experiment.

(Rafferty, 1969) as a way to further confirm the specificity of the antibody to the Xenopus protein. As shown in Figure 1 (lane $3)$, the A6 cell lysate also exhibited a prominent band at $18 \mathrm{kDa}$ when the Western blot was probed with the anti-HB-GAM antibody.

Since HB-GAM is a heparin-binding molecule, it may be bound to the HSPG at the cell surface. To test this, we treated cultures with heparinase, collected and concentrated the conditioned medium, and probed it with the HB-GAM antibody. We found that most of the HB-GAM was released into the medium in both A6 (Fig. 1, lane 5) and muscle (Fig. 1, lane 7) cultures by heparinase. Only a small amount of this protein was left on cells after enzymatic treatment (Fig. 1, lane 6 for A6 and lane 8 for muscle). These studies suggest that the bulk of HB-GAM is present on the cell surface in a heparinase-sensitive manner.

\section{Immunolocalization of HB-GAM}

Immunofluorescence studies were conducted on live cultures to determine the cellular localization of this molecule. As shown in Figure 2, $A$ and $B$, HB-GAM antibody labeled the cell surface in a punctate, streaky or filamentous pattern in noninnervated muscle cells. The confocal image in Figure $2 A$ shows that the entire cell surface was labeled. Most, but not all, of the labeling was removed by treating cells with heparinase (Fig. $2 B$ ) or with 

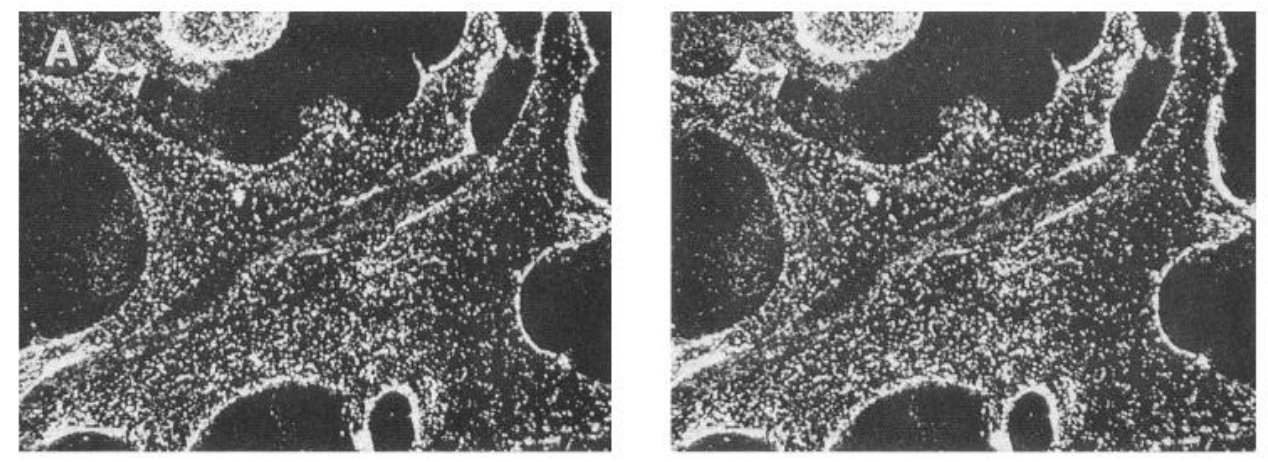

Figure 2. Confocal stereo image pairs of HB-GAM distribution on the surface of muscle cells before $(A)$ and after $(B)$ heparinase treatment. HB-GAM is present on the entire cell surface. Heparinase removes a significant amount of this protein from the cell surface. The arrowheads in $B$ point to residual HB-GAM staining after the enzymatic treatment. The larger fluorescent objects around the cell periphery are autofluorescent yolk granules released from damaged cells during dissociation.
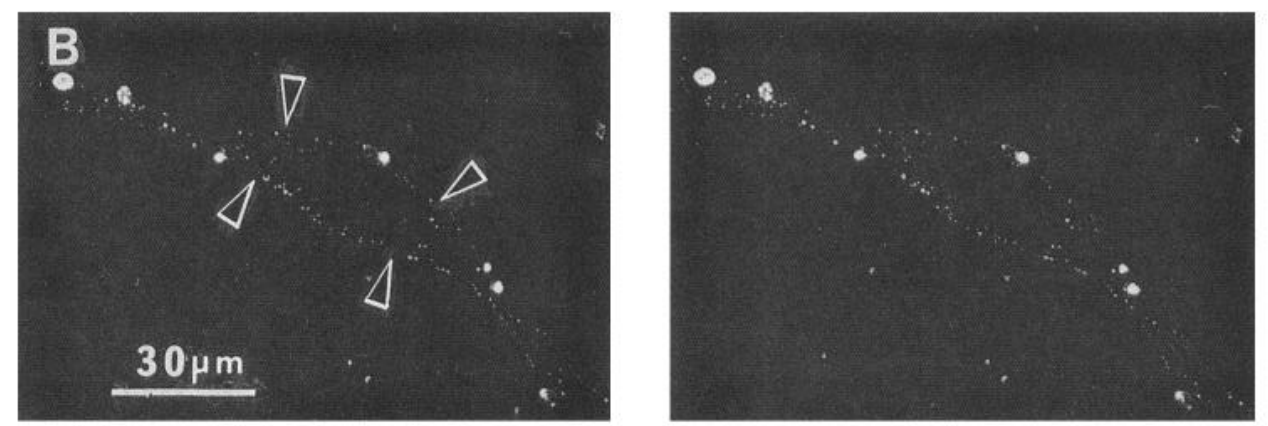

heparin (data not shown). Heparinase partially removes heparansulfate glycosaminoglycan (GAG) side chains from the core protein of HSPG, whereas heparin presumably solubilizes factors that are bound to HSPG at the cell surface. These results thus indicate that HB-GAM is associated with HSPG at the surface of Xenopus muscle cells, in consistency with Western blot data presented above. A punctate labeling pattern of HB-GAM was also observed on the surface of A6 cells and heparinase also abolished the bulk of the labeling on these cells (data not shown). In addition to the diffusely distributed pattern, patches of the cell surface where HB-GAM was concentrated were also observed (Figs. $3 B, D ; 4 B, D, F$ ). These HB-GAM hot spots were, in fact, often colocalized with AChR clusters (Fig. 4) as described below. No difference in the appearance of HB-GAM labeling at $20^{\circ} \mathrm{C}$ versus $4^{\circ} \mathrm{C}$ was observed. This rules out the possibility that the labeling pattern is due to a redistribution of the antigen.

To demonstrate further the association of HB-GAM with HSPG, we double-labeled muscle cells with the rabbit polyclonal HB-GAM antibody and a mouse monoclonal antibody against heparan sulfate (mAb HepSS-1). The patterns of HB-GAM and HSPG hot spots were then compared. As shown in Figure 3, A and $B$, and $C$ and $D$, a good colocalization of these two molecules was often observed at these patches. However, this is not a constant feature as some of the HSPG patches were clearly under populated by HB-GAM as shown in Figure $3, E$ and $F$. This suggests that HB-GAM only occupies a fraction of the available binding sites on the GAG chains of the HSPG molecules. By double labeling muscle cells with mAb HepSS-1 and a rabbit polyclonal antibody against perlecan (kindly provided by Dr. J. R. Hassell, University of Pittsburgh), the major basement-membrane HSPG (Noonan et al., 1991), we recently found that the HSPG that HB-GAM binds to is indeed perlecan (D.F.D. and H.B.P., unpublished results).

In our previous study, we showed that exogenously applied bFGF binds to HSPG at the surface of Xenopus muscle cells
(Baker et al., 1992). To determine whether the site on HSPG occupied by HB-GAM is also recognized by bFGF, we incubated cells with a $1 \mu \mathrm{g} / \mathrm{ml}$ solution of bFGF for $30 \mathrm{~min}$ and then doubly labeled them with the HB-GAM antibody and a mouse monoclonal antibody against bFGF. Our results showed that the application of exogenous bFGF nearly abolished HB-GAM staining (Fig. 3G,H). This observation shows that exogenous bFGF was able to displace the endogenous HB-GAM from its binding sites on the HSPG. To determine whether this displacement was simply due to the basic nature of bFGF, we also examined the effect of another heparin-binding protein amphoterin (p30), which is highly basic in its N-terminal amino-acid composition (Merenmies et al., 1991), and two polycations, polyornithine and polylysine. We found that amphoterin at $1 \mu \mathrm{g} / \mathrm{ml}$ was much less effective and polyornithine and polylysine at similar concentration were ineffective in displacing HB-GAM. Thus, bFGF and HB-GAM may compete specifically for the same GAG sequences of HSPG.

\section{Colocalization of HB-GAM with AChR clusters and the NMJ}

To understand whether HB-GAM is involved in the formation of AChR clusters in cultured muscle cells, we compared the localization of these two molecules at sites where they were concentrated. Double labeling cultures with R-BTX and HBGAM and FITC-conjugated secondary antibody showed a general colocalization of HB-GAM antibody and AChR hot spots in uninnervated muscle cells (Fig. $4 A-D$ ). However, when examined at high magnification as in Figure $4 A-D$, it became clear that these two types of specializations were not identical despite their colocalization. The HB-GAM clusters were in general slightly larger than the AChR clusters (Fig. 4C,D). Quantitation of this relationship showed that $61 \%$ of AChR hot spots were substantially overlapped by HB-GAM (as shown in Fig. $4 A-D$ ), $31 \%$ of them showed partial overlap and $8 \%$ were not correlated with HB-GAM at all $(n=144)$. We also examined the relationship between these two molecules at bead-induced AChR clus- 

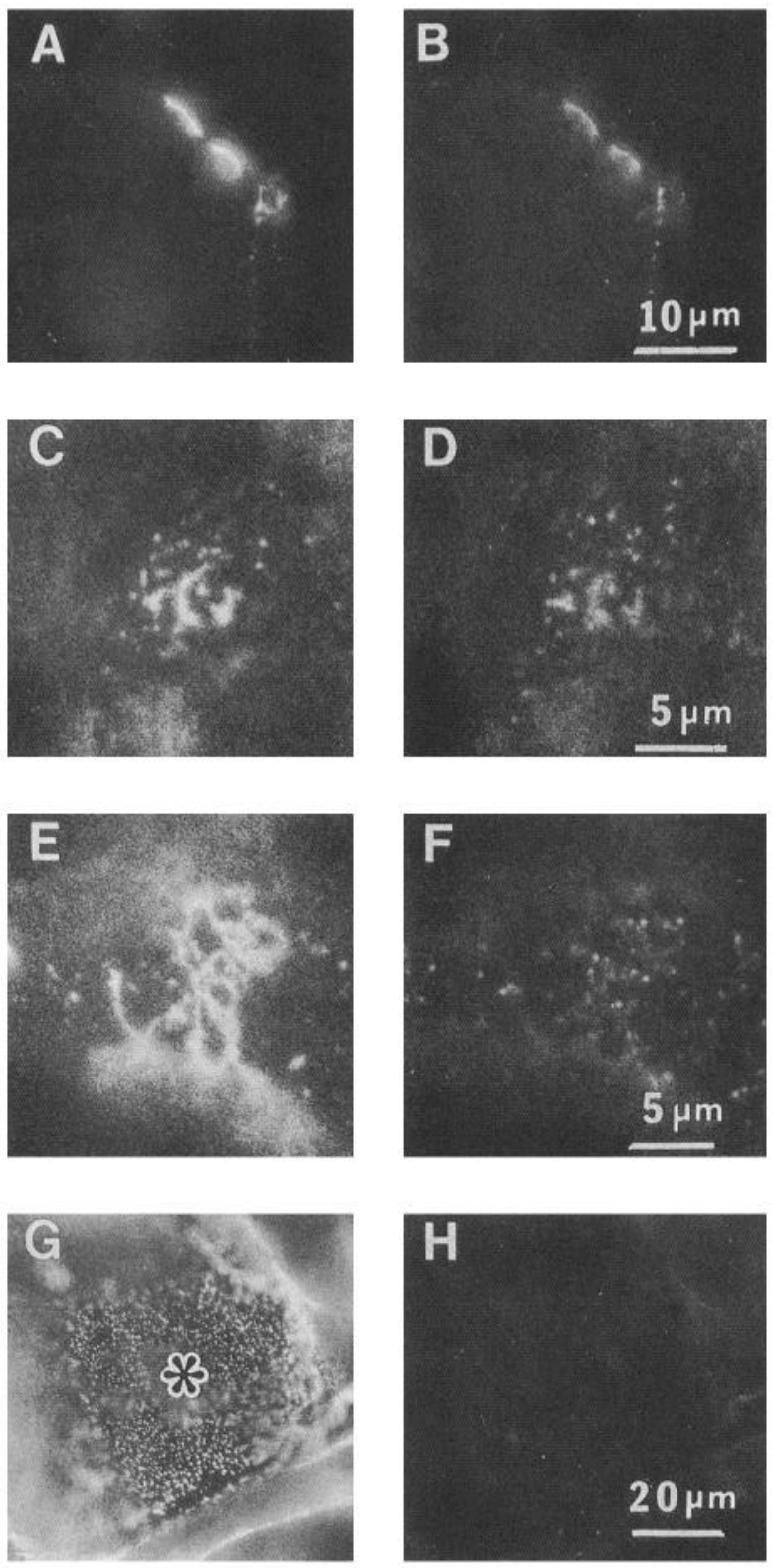

Figure 3. $A-F$, Correlation between HSPG and HB-GAM in muscle cells. Cultures were double labeled with a heparan-sulfate antibody $(A$, $C, E)$ and HB-GAM antibody $(B, D, F)$. The top two examples $(A-B$ and $C-D$ ) show good spatial correlation of HSPG and HB-GAM hot spots. In the third example $(E-F)$, only a small amount of HB-GAM is associated with this HSPG hot spot. $(G-H)$ Applying recombinant bFGF ( $1 \mu \mathrm{g} / \mathrm{ml}$ for $30 \mathrm{~min}$ ) to the cells resulted in bright bFGF labeling (asterisk in $G$ ) at the expense of HB-GAM $(H)$. This shows that bFGF can compete with HB-GAM for binding sites on HSPG.

ters. In this study, uncoated polystyrene beads were used to induce receptor clustering according to previous methods (Baker et al., 1992). As shown in Figure $4, E$ and $F$, HB-GAM was also concentrated at bead-induced AChR clusters, although there was a discrepancy both in morphology and in size.

To study the influence of innervation on HB-GAM distribution, we cocultured muscle cells with neurons dissociated from neural tubes of Xenopus embryos. R-BTX labeling revealed the formation of NMJ at $50 \%-90 \%$ of the nerve-muscle contacts as evidenced by the clustering of AChRs. Double labeling with both R-BTX and HB-GAM antibody showed that this molecule was concentrated at AChR clusters at the NMJ. Two examples of this colocalization are shown in Figure 5. These nerve-induced AChR clusters were generally associated with a relatively precise colocalization of HB-GAM. Thus, innervation induces both AChRs and HB-GAM to cluster at the nerve-muscle contact. It should be noted, however, that the HB-GAM was still present diffusely at extrasynaptic membrane even after innervation (Fig. 5B,E). Labeling live, cultured Xenopus spinal cord neurons not in contact with muscle cells showed no HB-GAM at their surface (H.B.P., unpublished results).

HB-GAM was also detected at AChR clusters in C2C12 myotubes by immunostaining with the anti-recombinant HB-GAM antibody and with an affinity-purified anti-HB-GAM peptide antibody that binds to the rodent sequence (Rauvala, 1989), whereas polyclonal antibodies to the mouse midkine protein did not stain these myotubes (data not shown). This indicates that the immunostaining of AChR clusters by the HB-GAM antibodies is not due to midkine, another member of this protein family. Thus, the colocalization of HB-GAM with AChR clusters is a conserved phenomenon from Xenopus to mouse.

\section{Induction of AChR clustering by local presentation of $\mathrm{HB}$ -} GAM via beads

To examine whether HB-GAM can function as an inducer for postsynaptic development in skeletal muscle, we locally applied this molecule to cultured Xenopus muscle cells via beads. Polystyrene $10 \mu \mathrm{m}$ latex beads were coated with recombinant rat HB-GAM by incubating them in a solution containing HB-GAM at a concentration of $100 \mu \mathrm{g} / \mathrm{ml}$ for several hours. Beads coated with HB-GAM showed intense fluorescence after labeling with HB-GAM antibody and fluorescent secondary antibody, indicating the adsorption of HB-GAM to the beads. Control beads coated with bovine serum albumin (BSA), fetal bovine serum, or other factors, such as EGF, NGF, and PDGF, were not labeled by the antibody (data not shown). These beads were then applied to muscle cultures. After an incubation period ranging from 6 to $24 \mathrm{hr}$, the cultures were labeled with R-BTX. As shown in Figure 6, a high percentage (between $60 \%$ and $90 \%$ ) of beadmuscle contacts were associated with AChR clusters. These clusters were discretely localized to the contact area. In contrast, control beads coated with BSA, serum proteins, EGF, PDGF, NGF, immunoglobulins, laminin, or tenascin were ineffective in inducing AChR clustering even though they also adhered to the cells (Peng et al., 1991a). The efficacy of the beads in inducing AChR clustering depends on the surface HB-GAM concentration. Beads incubated in a solution containing $10 \mu \mathrm{g} / \mathrm{ml}$ or less of HB-GAM were ineffective in inducing $\mathrm{AChR}$ clustering and there was an abrupt increase in the cellular response at $25 \mu \mathrm{g} / \mathrm{ml}$ incubation concentration.

In addition to inducing $\mathrm{AChR}$ clustering at sites of contact, these HB-GAM-coated beads were also effective in causing a dispersal of preexisting AChR hot spots at sites away from the beads (data not shown). Thus, these beads can mimic two effects of nerve innervation on the skeletal muscle: the local induction of AChR clustering at nerve-muscle contacts and the global dispersal of AChR hot spots at extrasynaptic sites.

\section{The role of tyrosine kinase activation in the bead-induced AChR clustering}

To test whether the effect of HB-GAM in inducing AChR clustering is mediated by a cell surface receptor, we studied the effect of suramin on the bead-induced AChR clustering. Suramin 

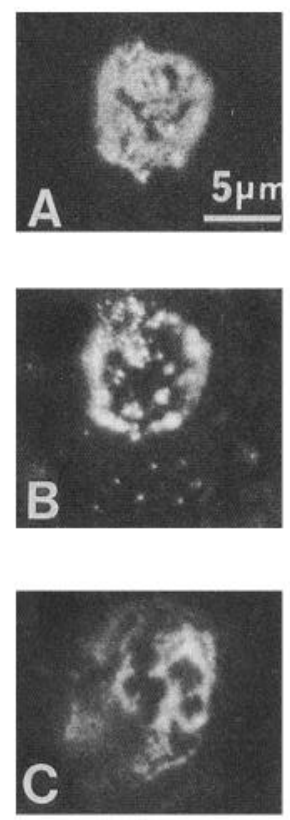

Figure 4. Association of HB-GAM with AChR clusters. $A, C, E$, R-BTX labeling; $B, D, F$, HB-GAM labeling. HB-GAM is closely associated with preexisting AChR hot spots (left column) or bead-induced clusters (right column, arrowheads), although they are not congruent in their fine patterns.
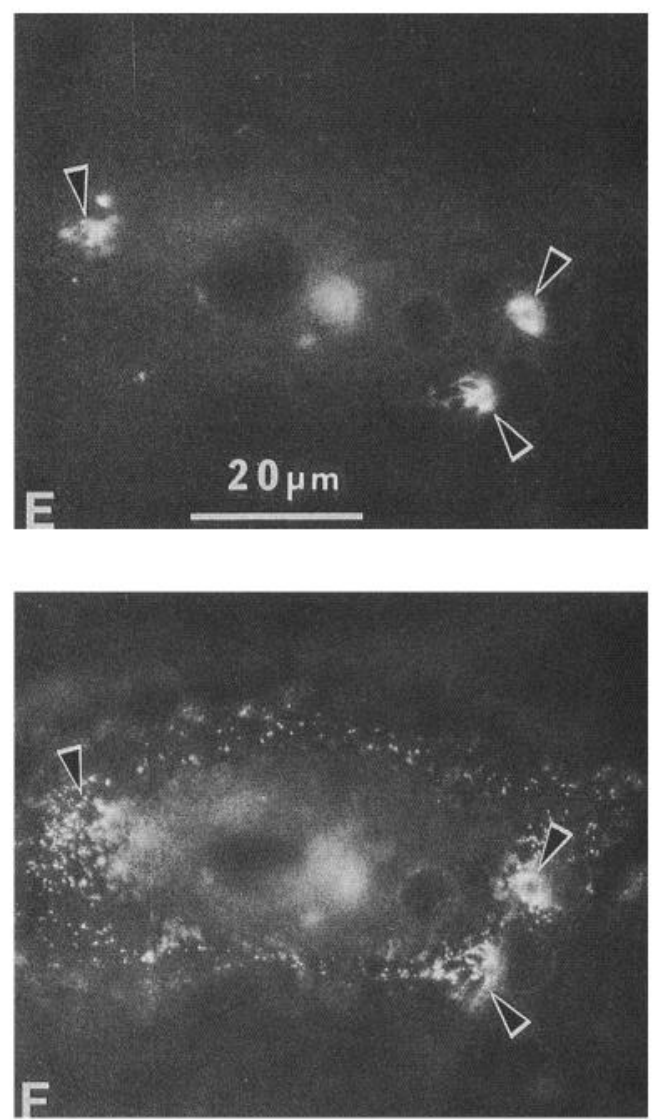

is a small (MW 1500), polyanionic molecule that has been widely used to interfere with the ligand-receptor interaction involved in peptide growth factor signaling (Betsholtz et al., 1986; Coffey et al., 1987; Huang and Huang, 1988; Fleming et al., 1989; Behrendt et al., 1993). At a concentration of $100 \mu \mathrm{M}$, suramin reduced the percentage of HB-GAM bead-muscle contacts that were positive in AChR clusters to $30 \%$ of the control value. The clusters that did form in the presence of suramin were much smaller in size. The median cluster size was about $10.3 \mu \mathrm{m}^{2}$ in the control $(n=100)$ and was reduced to $2.7 \mu \mathrm{m}^{2}$ in $50 \mu \mathrm{M}$ suramin $(n=100)$.

Although the receptor for HB-GAM has not been elucidated, we suspected that the activation of a tyrosine kinase-mediated signaling pathway may be involved in the induction of AChR clustering by this molecule as suggested by previous studies $(\mathrm{Qu}$ et al., 1990; Wallace et al., 1991; Baker and Peng, 1993). This was tested by the use of the tyrosine kinase inhibitor tyrphostin RG-50864 (Lyall et al., 1989; Levitzki and Gilon, 1991; Seckl and Rozengurt, 1993). As shown in Figure 7, the efficacy of beads in inducing AChR clustering was blocked by this compound with a half-inhibitory concentration of $50 \mu \mathrm{M}$. Cells remain viable at these concentrations of tyrphostin as shown in previous studies (Peng et al., 1991a; Baker and Peng, 1993). In addition to blocking the formation of AChR clusters, tyrphostin also abolished the effect of beads in causing the dispersal of preexisting AChR hot spots (data not shown). Thus, this tyrosine kinase inhibitor reversed both the local, cluster-inducing and the global, cluster-dispersing effects of the beads. An inactive form of tyrphostin, RG-50862, was used as a control in these studies and was found to have no effect on bead-induced AChR clustering.

\section{Effect of bath HB-GAM application on NMJ formation}

To further understand the role of HB-GAM in NMJ formation, we investigated the effect of interfering with the local HB-GAM signaling in the formation of AChR clusters induced by N-M contact. Since a good neutralizing antibody against HB-GAM had not been generated, we tested the effect of exogenous HBGAM in AChR clustering. Muscle cultures were treated with recombinant HB-GAM and then seeded with spinal cord neurons. After an 18-24 hr coculture period, the cultures were labeled with R-BTX and AChR clustering at N-M contacts was assessed. The percentage of contacts that exhibited AChR clustering was determined by scoring all of the clearly identifiable contacts in each culture. In control cultures not treated with HBGAM, more than $90 \%$ of contacts exhibited AChR clustering in this series of experiments. HB-GAM at a concentration of 25 $50 \mu \mathrm{g} / \mathrm{ml}(1.4-2.8 \mu \mathrm{M})$ significantly suppressed the nerve-induced clustering process and essentially abolished it at 75-100 $\mu \mathrm{g} / \mathrm{ml}(4.2-5.6 \mu \mathrm{M})$ (Fig. 8). An example of this suppression is shown in Figure 9 (compare $A$ with $B$ and $C$ ). Clusters that did develop at these high HB-GAM concentrations appeared to be more diffuse and less intense than the control ones (Fig. 9D). Bath application of HB-GAM, however, did not result in an increase in the formation of AChR clusters in extrasynaptic area of nerve-contacted muscle cells or in noninnervated muscle cells. Nor did we observe a decrease in the number of AChR hot spots at these concentrations. This suggests that the bath- 

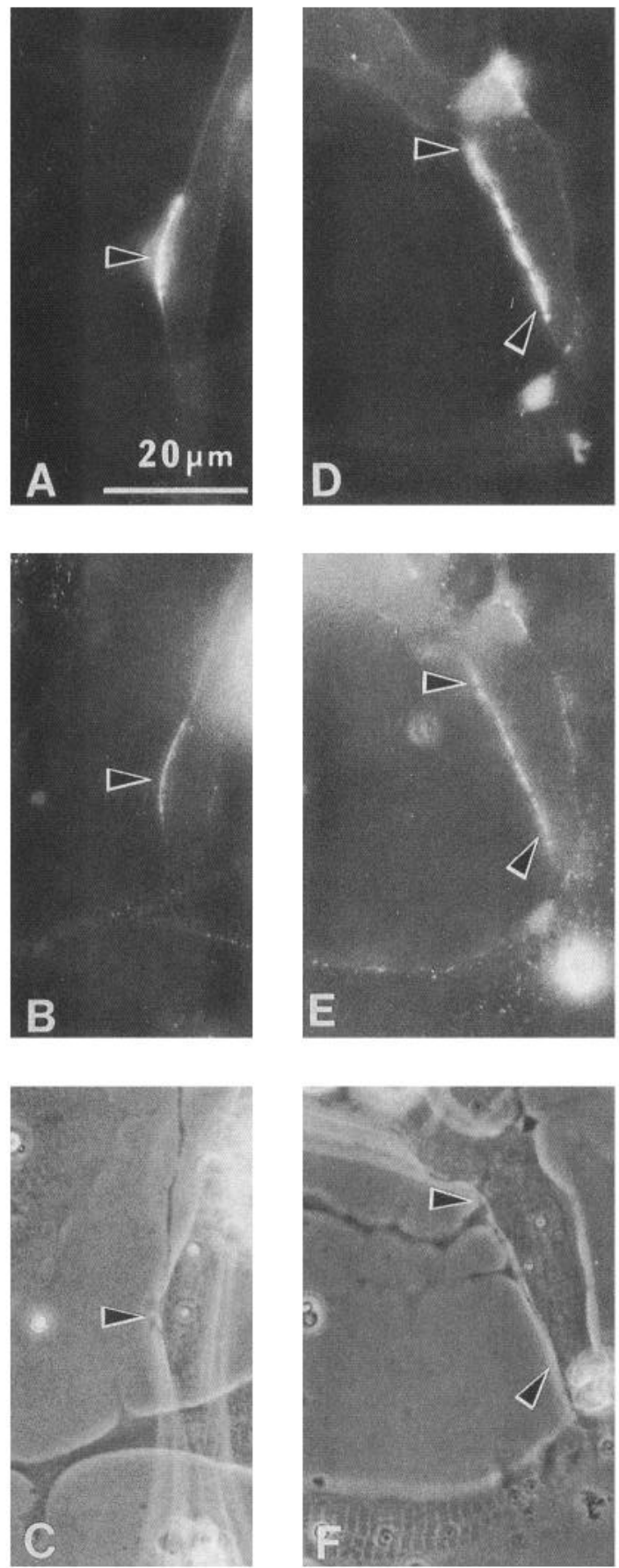

Figure 5. Association of HB-GAM with the NMJ in culture. The left and right columns are two different examples. $A, D$, R-BTX labeling; $B, E$, HB-GAM labeling; $C, F$, phase contrast. HB-GAM is concentrated at nerve-induced AChR clusters (arrowheads), although it is also present in extrajunctional areas $(B, E)$. The bright object at the lower righthand side of $E$ is a fluorescent cell debris.

applied HB-GAM did not cause deleterious effect on the muscle cell. When the HB-GAM concentration was raised to $200 \mu \mathrm{g} / \mathrm{ml}$, hot spots were indeed dispersed over a $24 \mathrm{hr}$ period. The cells remained viable even at this concentration.

To determine the specificity of the HB-GAM inhibition in nerve-induced AChR clustering, we also treated cultures with amphoterin (Atn), another heparin-binding protein that contains approximately the same proportion (28\%) of cationic, mainly
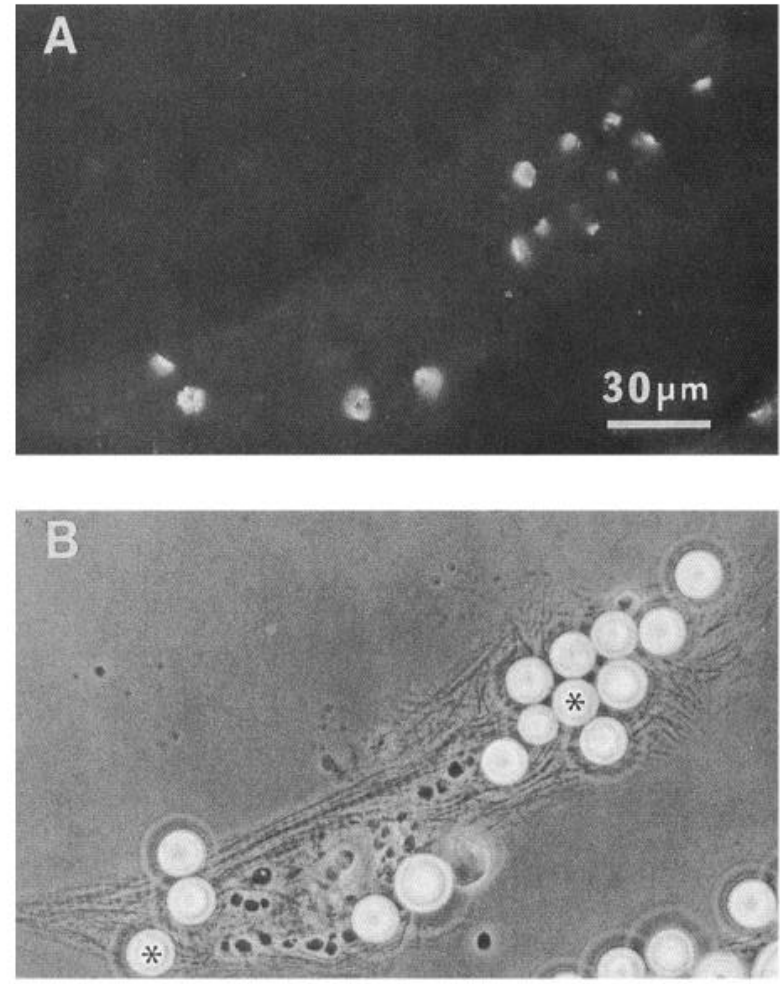

Figure 6. Induction of AChR clustering by HB-GAM-coated beads. R-BTX labeling $(A)$ revealed the high efficacy of these beads in inducing this specialization: only 2 out of a total of 15 bead-muscle contacts $(B$, asterisks) failed to induce clusters.

lysine, residues as in HB-GAM (Merenmies et al., 1991). As shown in Figures 8 and $9, E$ and $F$, this protein had no effect on nerve-induced $\mathrm{AChR}$ clustering at concentrations as high as $100 \mu \mathrm{g} / \mathrm{ml}$.

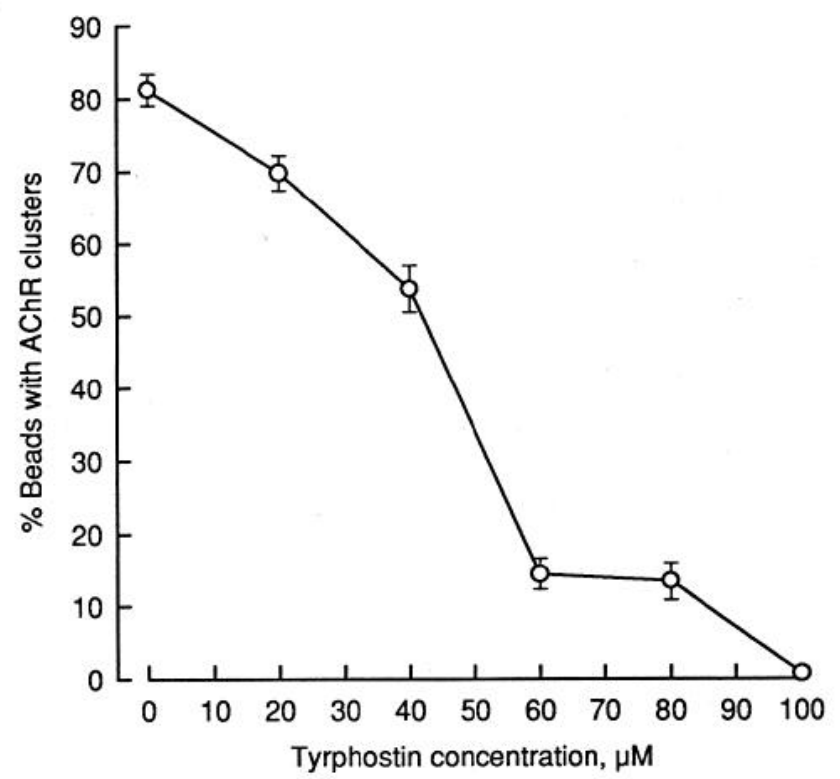

Figure 7. Inhibition of AChR clustering induced by HB-GAM-coated beads by the tyrosine kinase inhibitor tyrphostin RG50864. 


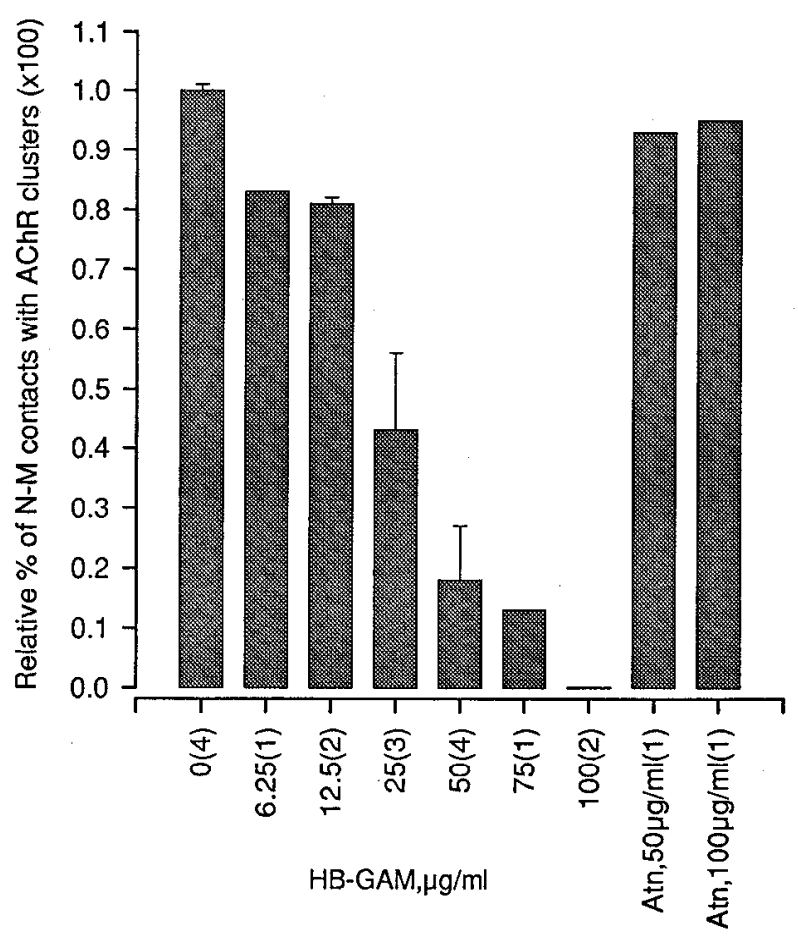

Figure 8. Effect of bath HB-GAM application on NMJ formation. The percentage of N-M contacts with AChR clustering was calculated from each $\mathrm{N}-\mathrm{M}$ coculture and is expressed as a relative value to the control culture. The value for each concentration is the mean of several experiments. The number of experiments for each concentration is indicated in the parentheses. The error bars are SEs. HB-GAM, at concentrations above $25 \mu \mathrm{g} / \mathrm{ml}$, significantly suppressed AChR clustering induced by the nerve. In contrast, another heparin-binding protein amphoterin (Atn) was ineffective.

\section{Distribution of $H B-G A M$ in vivo}

To begin to understand the role of HB-GAM in vivo, we conducted preliminary experiments to examine its distribution in Xenopus embryos. Dorsal embryo pieces were labeled with HBGAM antibody followed by fluorescent secondary antibody in living state without fixation, similar to the method used in labeling cell cultures described above. As shown in Figure 10, A and $C$ (arrowheads), HB-GAM labeling was observed within the space between adjacent myotomes in embryos at stage 22-24. This intermyotomal area, filled with various ECM molecules, is traversed by processes from motoneurons to establish NMJs at the ends of the myotomal muscle fibers which abut this space. However, at this early stage, NMJs had not formed as shown by the absence of AChR clusters (Fig. 10B). When older embryos (after stage 30) were examined, more prominent HB-GAM labeling was detected in this region (Fig. 10D). At these later stages, the HB-GAM localization was comparable to the sites of NMJs as shown by the location of AChR clusters (Fig. 10E). These data suggest that HB-GAM is first concentrated at future sites of NMJ formation prior to the arrival of the nerve and later becomes colocalized with the junctions. HB-GAM was absent from the notochord with the live-labeling method employed in this study.

\section{Discussion}

In this study, we have shown that HB-GAM is an endogenous muscle-derived factor normally stored on the HSPC at the surface of Xenopus muscle cells. Despite its concentration at AChR hot spots, this molecule is generally distributed in a diffuse manner on the cell surface in a pattern analogous to the HSPG distribution. Innervation results in concentration of HB-GAM at the NMJ. The induction of AChR clustering by HB-GAM-coated beads suggests a role for this molecule in signaling postsynaptic development. The activation of a tyrosine kinase-mediated pathway is probably involved in the signal transduction process activated by HB-GAM, since it is blocked by an inhibitor to tyrosine kinase. In addition, bath application of HB-GAM antagonizes the nerve-induced AChR clustering process. To our knowledge, this is the first demonstration of an endogenous peptide growth factor that colocalizes with a synapse and can act as its inducer.

Previous works have demonstrated two other roles for HBGAM. This molecule has been shown to be a neurite-promoting and guidance factor when it is bound to the substratum (Rauvala, 1989; Kuo et al., 1990; Li et al., 1990; Hampton et al., 1992; Raulo et al., 1992; Rauvala et al., 1994). In fact, neurons in the CNS are rich sources for HB-GAM (Rauvala et al., 1994). Immunocytochemical studies using fixed and permeabilized neurons have shown its presence in the soma and the neurite (Rauvala, 1989). Its absence from the surface of live neurites as shown in this study may be correlated with the lack of an extensive HSPC-containing ECM at the neuronal surface. HBGAM may also be a mitogen for certain cell lines ( $\mathrm{Li}$ et al., 1990; Fang et al., 1992), although this effect is controversial (Merenmies, 1992; Raulo et al., 1992). This molecule shares high amino acid homology with two other heparin-binding factors, midkine (Matsubara et al., 1990; Muramatsu et al., 1993) and retinoic acid-inducible heparin-binding factor, which may be the avian homolog of midkine (Vigny et al., 1989; Cockshutt et al., 1993). Thus, HB-GAM is a member of an emerging family of new HBGFs which may play regulatory roles in development.

Although the receptor for HB-GAM has not yet been elucidated, a recent study showed that this factor can be crosslinked to 127 and $155 \mathrm{kDa}$ cell surface proteins on NIH 3T3 cells (Kuo ct al., 1992) and can stimulate tyrosine phosphorylation of a 200 $\mathrm{kDa}$ protein in two fibroblast cell lines (Li and Deuel, 1993). Thus, a kinase-dependent signaling pathway is likely involved in the interaction of HB-GAM with cells. This is also supported by our current result that a tyrosine kinase inhibitor blocks AChR clustering induced by HB-GAM beads.

\section{The role of HSPG and its associated factors in synaptogenesis}

HSPGs are ubiquitous components of the ECM in a variety of cell types, including skeletal muscle and neurons (Ruoslahti, 1989; Bernfield et al., 1992; Yanagishita and Hascall, 1992; Halfter, 1993). Recent studies have elucidated two roles for this class of molecules. First, they serve as storage sites for HBGFs, such as bFGF, heparin-binding EGF, and HB-GAM (Rauvala, 1989; Rifkin and Moscatelli, 1989; Higashiyama et al., 1992). This provides a mechanism for localizing these factors to the cell surface, a strategic location for intercellular signaling. In addition, a second role for HSPG as an active participant in the signaling process has recently been elucidated (Klagsbrun and Baird, 1991; Ruoslahti and Yamaguchi, 1991). As shown in the case of bFGF receptor, the formation of a ternary complex, involving the receptor, bFGF and HSPG, is essential for cell stimulation (Rapraeger et al., 1991; Yayon et al., 1991; Kan et al., 1993). Whether this paradigm also applies to the action of IIBGAM awaits further studies. 

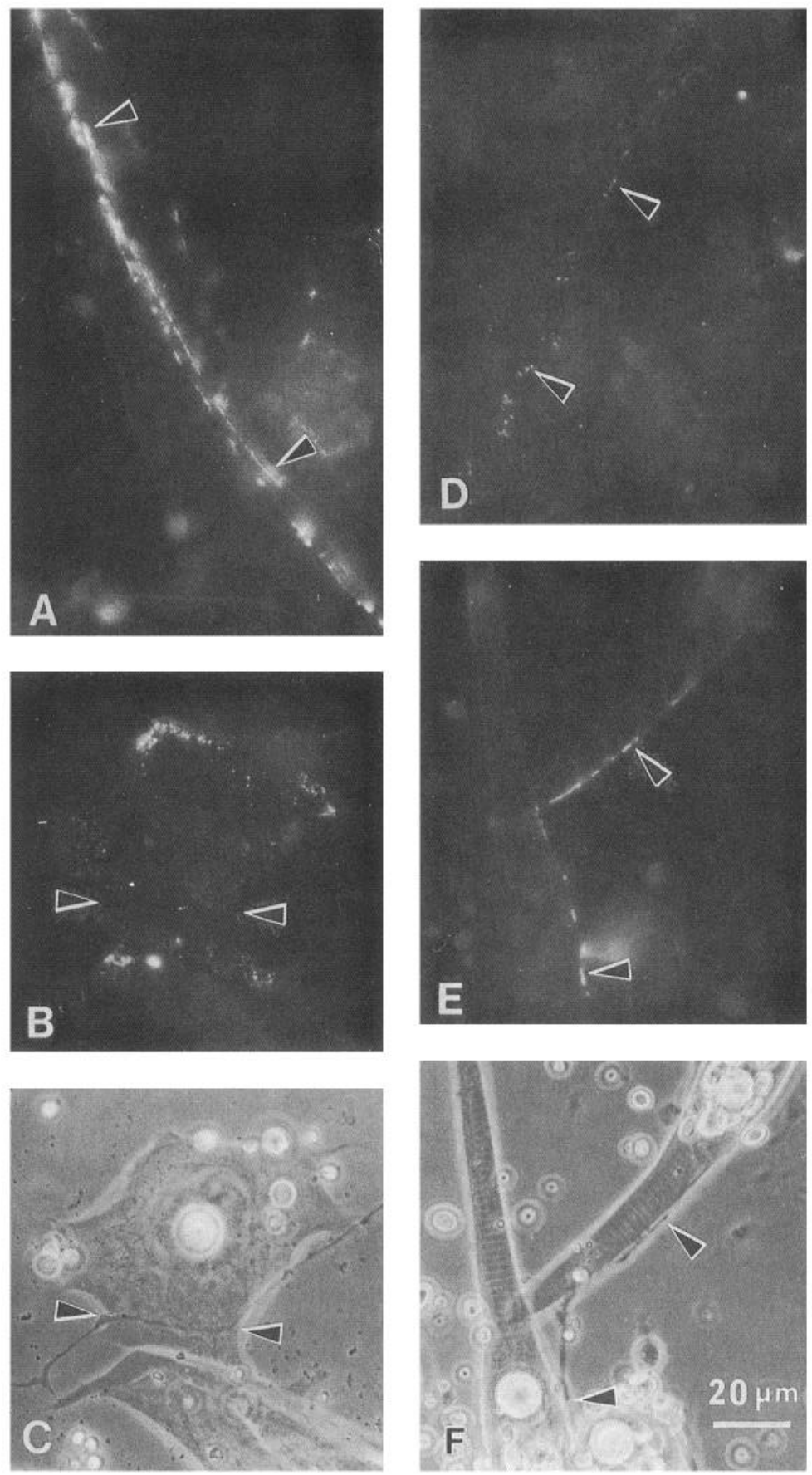

Figure 9. Effect of bath HB-GAM application on NMJ formation. $A$, NMJs in a control N-M coculture. The R-BTX labeling shows extensive clustering of AChRs (arrowheads) on two adjacent muscle cells innervated by a common nerve. $B, C$, In the presence of $50 \mu \mathrm{g} / \mathrm{ml} \mathrm{HB-GAM}$ in the bath, the nerve-induced AChR clustering was substantially suppressed as shown in this example. The N-M contact shown in $C$ (between arrowheads) was devoid of $\mathrm{AChR}$ clustering $(B)$, although hot spots were present on this muscle cell. $D$, At higher HB-GAM concentration (75 $\mu \mathrm{g} / \mathrm{ml})$, the few remaining nerveinduced clusters showed a diffuse appearance and were generally much dimmer than control ones as shown by R-BTX fluorescence. $E, F$, In contrast to HB-GAM, amphoterin at $100 \mu \mathrm{g} / \mathrm{ml}$ had no effect on AChR clustering induced by the nerve.
In the case of NMJ development, the involvement of HSPG in the induction of AChR clustering is suggested by several lines of evidence. First, HSPG is concentrated at the NMJ both in vivo and in vitro and is coclustered with AChRs during innervation of cultured muscle cells (Anderson and Fambrough, 1983; Anderson et al., 1984; Bayne et al., 1984). This property is also shared by HB-GAM as shown in this study. Second, culturing nerve and muscle cells in the presence of heparin and heparan sulfate, but not condroitin sulfate, suppresses the formation of AChR clustering induced by the nerve in culture (Hirano and Kidokoro, 1989; see also Baker et al., 1992). In genetic variants of the mouse $\mathrm{C} 2$ myotubes that are defective in GAG synthesis, either in its elongation or sulfation, spontaneous clustering of AChRs into hot spots fails to occur (Gordon and Hall, 1989;
Gordon et al., 1993). Recent studies have shown that heterokaryons of these defective cells that have restored GAG synthesis exhibit normal AChR clustering (Jung et al., 1993). This further illustrates the necessity of HSPGs in AChR clustering.

Our results suggest that the importance of HSPG in AChR clustering may lie in its association with HBGFs and HB-GAM is probably one such factor. The strong heparin-binding property of this class of proteins enables them to be localized in the ECM. When these molecules are bound to the HSPG, they exist in a kind of latent form. Upon cell-cell contact, these factors are locally presented to interacting cells and become active in signaling (Saksela and Rifkin, 1990). This presentation is presumably carried out by the nerve during innervation. The capability to present these molecules may be specific to the neuron, since 

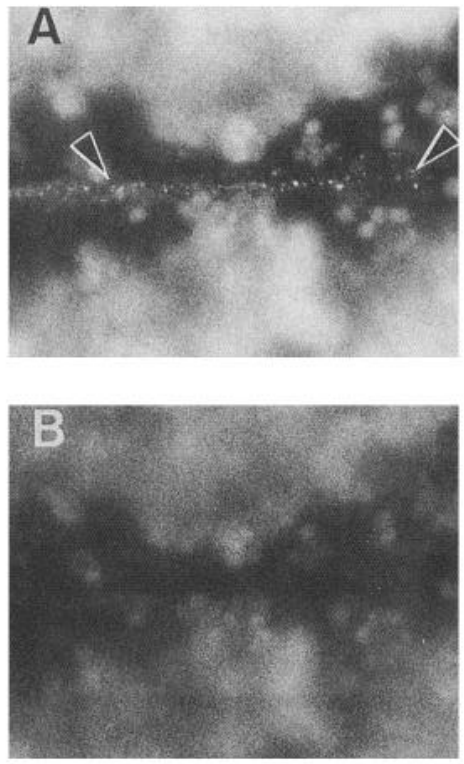

Figure 10. HB-GAM localization in the myotomes of the Xenopus embryo. $A-C$, Stage 24 embryo. HB-GAM was concentrated within the inter-myotomal region (arrowheads in $A$ ), which can be seen in bright field in $C$. At this stage, NMJs had not formed as shown by the absence of fluorescent BTX labeling in this region $(B)$. The myotomes $(M)$ contained a lot of yolk which yielded autofluorescent background as shown in $A$ and $B$. D-E, Stage 30-32 embryos. The HB-GAM labeling (arrowheads in $D$ ) can be seen more prominently in the intermyotomal region in these older embryos. This labeling pattern was comparable to the distribution of AChR clusters as shown by fluorescent BTX labeling (arrowheads in E).
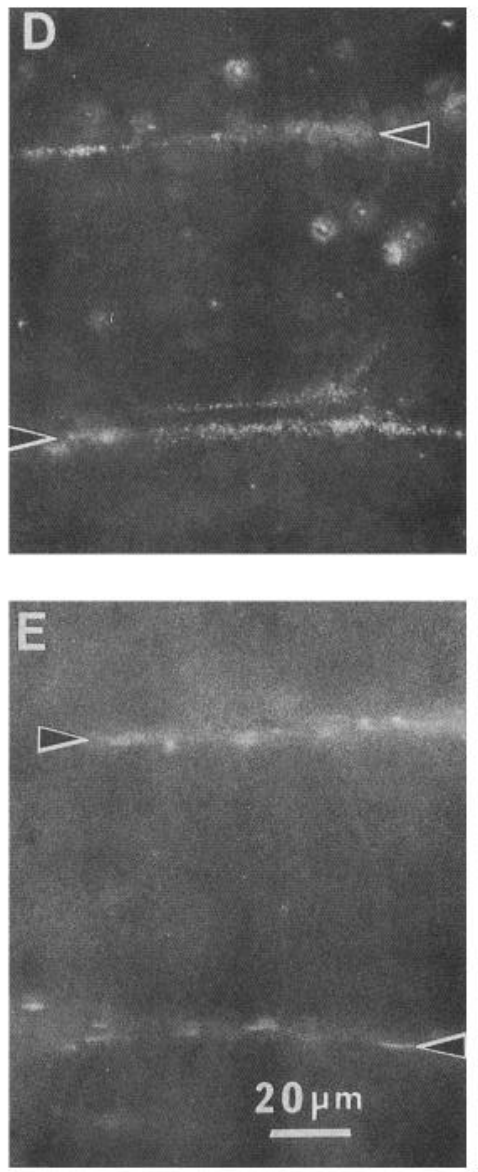

AChR clustering does not occur at muscle-muscle contact in Xenopus cultures. The nature of the presentation mechanism is unknown. Previous studies suggest that the release of proteases by the growth cone may modulate the HSPG at N-M contact to effect the presentation of its bound factors (Anderson, 1986; Seeds et al., 1992). Alternatively, the nerve may secrete specific molecules, such as neuronal HSPG (Halfter, 1993), that can competitively displace factors bound to the muscle HSPG to effect stimulation at the contact site. The stimulation probably involves the activation of a receptor tyrosine kinase by the locally displaced HB-GAM as our inhibitor study shows. In any event, our study demonstrates that beads can effectively mimic the nerve in presenting these factors to the muscle cell to effect synaptic induction. On the other hand, bath application of exogenous HB-GAM suppresses the cluster formation. This can be explained by the fact that muscle cells usually respond only to local signals presented by the nerve during synaptogenesis. When they are globally stimulated by exogenous ligand, the cell is most likely overwhelmed so that it can no longer discern the positional information provided by the nerve via its local presentation of endogenous HB-GAM, thus resulting in failure to cluster AChRs.

In agreement with the suggested role as a muscle-derived synaptogenic factor, HB-GAM is expressed in developing muscle in vivo. This was previously shown by Northern and Western blots (Li et al., 1990; Merenmies and Rauvala, 1990) and by in situ hybridization (Vanderwinden et al., 1992). Immunostaining of the rat limb buds shows that after the midgestation period (on embryonic days 15-17) HB-GAM is mainly found in desmin- positive muscle cells, in which it partially colocalizes with the AChR clusters (E. Szabat and H. Rauvala, unpublished results). The localization of this molecule at the intermyotomal junction where NMJs develop as revealed in this study is also consistent with its role in vivo. Significantly, the HB-HAM promoter contains several consensus (CANNTG) sequences for MyoD binding (Li et al., 1992; Milner et al., 1992). This suggests that the expression of HB-GAM is linked to muscle differentiation, which is known to be controlled by transcription factors of the MyoD family. The presence of MyoD binding sites within the HB-GAM promoter suggests a coordinate expression of $\mathrm{HB}$ GAM and AChR in muscle cells, since the expression of AChR subunits is also known to be controlled by MyoD-type transcription factors (Salpeter et al., 1992).

Extensive studies have established the central role of agrin, an ECM-bound molecule enriched at the NMJ, in directing postsynaptic differentiation (McMahan et al., 1992; Cohen et al., 1994; Bowe and Fallon, 1995). The results of this study suggest that agrin and HB-GAM may both be involved in postsynaptic induction. Whether these represent independent or overlapping pathways awaits further investigation.

\section{References}

Anderson MJ (1986) Nerve-induced remodeling of muscle basal lamina during synaptogenesis. J Cell Biol 102:863-877.

Anderson MJ, Fambrough DM (1983) Aggregates of acetylcholine receptors are associated with plaques of a basal lamina heparan sulfate proteoglycan on the surface of skeletal muscle fibers. J Cell Biol 97: 1396-1411.

Anderson MJ, Klier FG, Tanguay KE (1984) Acetylcholine receptor 
aggregation parallels the deposition of a basal lamina proteoglycan. J Cell Biol 99:1769-1784.

Baker LP, Peng HB (1993) Tyrosine phosphorylation and acetylcholine receptor cluster formation in cultured Xenopus muscle cells. J Cell Biol 120:185-195.

Baker LP, Chen Q, Peng HB (1992) Induction of acetylcholine receptor clustering by native polystyrene beads: implication of an endogenous muscle-derived signalling system. J Cell Sci 102:543-555.

Bayne EK, Anderson MJ, Fambrough DM (1984) Extracellular matrix organization in developing muscle: correlation with acetylcholine receptor aggregates. J Cell Biol 99:1486-1501.

Behrendt N, Ronne E, Dano K (1993) Binding of the urokinase-type plasminogen activator to its cell surface receptor is inhibited by low doses of suramin. J Biol Chem 268:5985-5989.

Bernfield M, Kokenyesi R, Kato M, Hinkes MT, Spring J, Gallo RL, Lose EJ (1992) Biology of the syndecans: a family of transmembrane heparan sulfate proteoglycans. Annu Rev Cell Biol 8:365-393.

Betsholtz C, Johnsson A, Heldin C-H, Westermark B (1986) Efficient reversion of simian sarcoma virus-transformation and inhibition of growth factor-induced mitogenesis by suramin. Proc Natl Acad Sci USA 83:6440-6444.

Bowe MA, Fallon JR (1995) The role of agrin in synapse formation. Annu Rev Neurosci, in press.

Brunner G, Gabrilove J, Rifkin DB, Wilson EL (1991) Phospholipase $\mathrm{C}$ release of basic fibroblast growth factor from human bone marrow cultures as a biologically active complex with a phosphatidylinositolanchored heparan sulfate proteoglycan. J Cell Biol 114:1275-1283.

Cockshutt AM, Régnier F, Vigny M, Raulais D, Chany-Fournier F (1993) Retinoic acid-induced heparin-binding factor (RIHB) mRNA and protein are strongly induced in chick embryo chondrocytes treated with retinoic acid. Exp Cell Res 207:430-438.

Coffey RJ, Leof EB, Shipley GD, Moses HL (1987) Suramin binding of growth factor receptor and mitogenicity in AKR-2B cells. J Cell Physiol 132:143-148.

Cohen MW, Moody-Corbett F, Godfrey EW (1994) Neurite deposition of agrin on culture substrate: implication for nerve-muscle synaptogenesis. J Neurosci 14:3293-3303.

Esch F, Baird A, Ling N, Ueno N, Hill F, Denoroy L, Klepper R, Gospodarowicz D, Bohlen P, Guillemin R (1985) Primary structure of bovine pituitary basic fibroblast growth factor and comparison with the amino-terminal sequence of bovine brain acidic FGF. Proc Natl Acad Sci USA 82:6507-6511.

Evans JP, Kay BK (1991) Biochemical fractionation of oocytes. In: Methods in cell biology, Vol 36, Xenopus laevis: practical uses in cell and molecular biology. (Kay BK, Peng HB, eds), pp 133-148. San Diego: Academic.

Fang W, Hartmann N, Chow DT, Riegel AT, Wellstein A (1992) Pleiotrophin stimulates fibroblasts and endothelial and epithelial cells and is expressed in human cancer. J Biol Chem 267:25889-25897.

Flaumenhaft R, Moscatelli D, Rifkin DB (1990) Heparin and heparan sulfate increase the radius of diffusion and action of basic fibroblast growth factor. J Cell Biol 111:1651-1659.

Fleming TP, Matsui T, Molloy CJ, Robbins KC, Aaronson SA (1989) Autocrine mechanism for $\mathrm{v}$-sis transformation requires cell surface localization of internally activated growth factor receptors. Proc Natl Acad Sci USA 86:8063-8067.

Giloh H, Sedat JW (1982) Fluorescence microscopy: reduced photobleaching of rhodamine and fluorescein protein conjugates by n-propyl gallate. Science 217:1252-1255.

Gordon H, Hall ZW (1989) Glycosaminoglycan variants in the C2 muscle cell line. Dev Biol 135:1-11.

Gordon H, Lupa M, Bowen D, Hall Z (1993) A muscle cell variant defective in glycosaminoglycan biosynthesis forms nerve-induced but not spontaneous clusters of the acetylcholine receptor and the $43 \mathrm{kDa}$ protein. J Neurosci 13:586-595.

Halfter W (1993) A heparan sulfate proteoglycan in developing avian axonal tracts. J Neurosci 13:2863-2873.

Hall ZW, Sanes JR (1993) Synaptic structure and development: the neuromuscular junction. Neuron [Suppl] 10:99-121.

Hampton BS, Marshak DR, Burgess WH (1992) Structural and functional characterization of full-length heparin-binding growth associated molecule. Mol Biol Cell 3:85-93.

Higashiyama S, Lau K, Besner GE, Abraham JA, Klagsbrun M (1992) Structure of heparin-binding EGF-like growth factor. Multiple forms, primary structure, and glycosylation of the mature protein. J Biol Chem 267:6205-6212.

Higashiyama S, Abraham JA, Klagsbrun M (1993) Heparin-binding EGF-like growth factor stimulation of smooth muscle cell migration: dependence on interactions with cell surface heparan sulfate. J Cell Biol 122:933-940.

Hirano Y, Kilokoro Y (1989) Heparin and heparan sulfate partially inhibit induction of acetylcholine receptor accumulation by nerve in Xenopus culture. J Neurosci 9:1555-1561.

Huang SS, Huang JS (1988) Rapid turnover of the platelet-derived growth factor receptor in sis-transformed cells and reversal by suramin. J Biol Chem 263:12608-12618.

Jung IM, Chen J, Gordon H (1993) AChR clustering is restored by complementation between proteoglycan-defective variants in the $\mathrm{C} 2$ muscle cell line. Mol Biol Cell [Suppl] 4:71a.

Kadomatsu K, Tomomura M, Muramatsu T (1988) cDNA cloning and sequencing of a new gene intensely expressed in early differentiation stages of embryonal carcinoma cells and in mid-gestation period of mouse embryogenesis. Biochem Biophys Res Commun 151:13121318.

Kan M, Wang F, Xu J, Crabb JW, Hou J, McKeehan WL (1993) An essential heparin-binding domain in the fibroblast growth factor receptor kinase. Science 259:1918-1921.

Klagsbrun M, Baird A (1991) A dual receptor system is required for basic fibroblast growth factor activity. Cell 67:229-231.

Kretschmer PJ, Fairhurst JL, Decker MM, Chan CP, Gluzman Y, Bohlen P, Kovesdi I (1991) Cloning, characterization and developmental regulation of two members of a novel human gene family of neurite outgrowth-promoting proteins. Growth Factors 5:99-114.

Kuo M-D, Oda Y, Huang JS, Huang SS (1990) Amino acid sequence and characterization of a heparin-binding neurite-promoting factor (p18) from bovine brain. J Biol Chem 265:18749-18752.

Kuo MD, Huang SS, Huang JS (1992) Characterization of heparinbinding growth-associated factor receptor on NIH $3 \mathrm{~T} 3$ cells. Biochem Biophys Res Commun 182:188-194.

Kure S, Yoshie O (1986) A syngeneic monoclonal antibody to murine Meth-A sarcoma (HepSS-1) recognizes heparan sulfate glycosami noglycan (HS-GAG): cell density and transformation dependent alteration in cell surface HS-GAG defined by HepSS-1. J Immunol 137: 3900-3908.

Laemmli UK (1970) Clevage of structural proteins during the assembly of the head of bacteriophage T4. Nature 227:680-685.

Levitzki A, Gilon C (1991) Tyrphostins as molecular tools and potential antiproliferative drugs. Trends Pharmacol Sci 12:171-174.

I i Y-S, Delvel TF (1993) Pleiotrophin stimulates tyrosine phosphorylation in NIH 3T3 and NB41A3 cells. Biochem Biophys Res Commun 195:1089-1095.

Li Y-S, Milner PG, Chauhan AK, Watson MA, Hoffman RM, Kodner CM, Milbrandt J, Deuel TF (1990) Cloning and expression of a developmentally regulated protein that induces mitogenic and neurite outgrowth activity. Science 250:1690-1694.

Li Y-S, Hoffman RM, Le Beau MM, Espinosa R, III, Jenkins NA, Gilbert DJ, Copeland NG, Deuel TF (1992) Characterization of the human pleiotrophin gene. Promoter region and chromosomal localization. J Biol Chem 267:26011-26016.

Lyall RM, Zilberstein A, Gazit A, Gilon C, I evitzki A, Schlessinger J (1989) Tyrphostins inhibit epidermal growth factor (EGF)-receptor tyrosine kinase activity in living cells and EGF-stimulated cell proliferation. J Biol Chcm 264:14503-14509.

Matsubara S, Tomomura M, Kadomatsu K, Muramatsu T (1990) Structure of a retinoic acid-responsive gene, $\mathrm{MK}$, which is transiently activated during the differentiation of embryonal carcinoma cells and the mid-gestation period of mouse embryogenesis. J Biol Chem 265: 9441-9443.

McMahan UJ, Horton SE, Werle MJ, Honig LS, Kroger S, Ruegg MA, Escher $G$ (1992) Agrin isoforms and their role in synaptogenesis. Curr Opin Cell Biol 4:869-874.

Merenmies J (1992) Cell density-dependent expression of heparinbinding growth-associated molecule (HB-GAM, p18) and its downregulation by fibroblast growth factors. FEBS Lett 307:297-300.

Merenmies J, Rauvala H (1990) Molecular cloning of the $18-\mathrm{kDa}$ growth-associated protein of developing brain. J Biol Chem 265: 16721-16724.

Merenmies J, Pihlaskari R, Laitinen J, Wartiovaara J, Rauvala H (1991) 
30-kDa heparin-binding protein of brain (amphoterin) involved in neurite outgrowth. J Biol Chem 266:16722-16729.

Mignatti P, Morimoto T, Rifkin DB (1992) Basic fibroblast growth factor, a protein devoid of secretory signal sequence, is released by cells via a pathway independent of the endoplasmic reticulum-Golgi complex. I Cell Physiol 151:81-93.

Milner PG, Shah D, Veile R, Donis Keller H, Kumar BV (1992) Cloning, nucleotide sequence, and chromosome localization of the human pleiotrophin gene. Biochemistry 31:12023-12028.

Muramatsu $\mathrm{H}$, Shirahama $\mathrm{H}$, Yonezawa $\mathrm{S}$, Maruta $\mathrm{H}$, Muramatsu $\mathrm{T}$ (1993) Midkine, a retinoic acid-inducible growth/differentiation factor: immunochemical evidence for the function and distribution. Dev Biol 159:392-402.

Noonan DM, Fulle A, Valente P, Cai S, Horigan E, Sasaki M, Yamada Y, Hassell JR (1991) The complete sequence of perlecan, a basement membrane heparan sulfate proteoglycan, reveals extensive similarity with laminin A chain, low density lipoprotein-receptor, and the neural cell adhesion molecule. J Biol Chem 266:22939-22947.

Parkkinen J, Raulo E, Merenmies J, Nolo R, Kajander EO, Baumann M, Rauvala H (1993) Amphoterin, the 30-kDa protein in a family of HMG1-type polypeptides. Enhanced expression in transformed cells, leading edge localization, and interactions with plasminogen activation. J Biol Chem 268:19726-19738.

Peng HB, Baker LP, Chen Q (1991a) Induction of synaptic development in cultured muscle cells by basic fibroblast growth factor. Neuron 6:237-246.

Peng HB, Baker LP, Chen Q (1991b) Tissue culture of Xenopus neurons and muscle cells as a model for studying synaptic induction. In: Methods in cell biology, Vol 36, Xenopus laevis: practical uses in cell and molecular biology (Kay BK, Peng HB, eds), pp 511-526. San Diego: Academic.

Qu Z, Moritz E, Huganir RL (1990) Regulation of tyrosine phosphorylation of the nicotinic acetylcholine receptor at the rat neuromuscular junction. Neuron 4:367-378.

Rafferty KA Jr (1969) Mass culture of amphibian cells: methods and observations concerning stability of cell type. In: Biology of amphibian tumors (Mizell M, ed), pp 52-81. New York: Springer.

Rapraeger AC, Krufka A, Olwin BB (1991) Requirement of heparan sulfate for bFGF-mediated fibroblast growth and myoblast differentiation. Science 252:1705-1708.

Raulo E, Julkunen I, Merenmies J, Pihlaskari R, Rauvala H (1992) Sccrction and biological activities of heparin-binding growth-associated molecule. Neurite outgrowth-promoting and mitogenic actions of the recombinant and tissue-derived protein. J Biol Chem 267: $11408-11416$.

Rauvala H (1989) An 18-kd heparin-binding protein of developing brain that is distinct from fibroblast growth factors. EMBO J 8:29332941.

Rauvala H, Merenmies J, Pihlaskari R, Korkolainen M, Huhtala M-L, Panula $P$ (1988) The adhesive and neurite-promoting molecule p30: analysis of the amino-terminal sequence and production of antipep- tide antibodies that detect p30 at the surface of neuroblastoma cells and of brain neurons. J Cell Biol 107:2293-2305.

Rauvala H, Vanhala A, Castrén E, Nolo R, Raulo E, Merenmies J, Panula P (1994) Expression of HB-GAM (heparin-binding growthassociated molecule) in the pathways of developing axonal processes in vivo and HB-GAM-induced neurite outgrowth in vitro. Dev Brain Res 79:157-176.

Rifkin DB, Moscatelli D (1989) Recent developments in the cell biology of basic fibroblast growth factor. J Cell Biol 109:1-6.

Risau W, Ekblom P (1986) Production of a heparin-binding angiogenesis factor by the embryonic kidney. J Cell Biol 103:1101-1107.

Ruoslahti E (1989) Protcoglycans in cell regulation. J Biol Chem 264: $13369-13372$

Ruoslahti E, Yamaguchi Y (1991) Proteoglycans as modulators of yrowih factor activities. Cell 64:867-869.

Saksela O, Rifkin DB (1990) Release of basic fibroblast growth factorheparan sulfate complexes from endothelial cells by plasminogen activator-mediated proteolytic activity. J Cell Biol 1 10:767-775.

Salmivirta M, Heino J, Jalkanen M (1992) Basic fibroblast growth factor-syndecan complex at cell surface or immobilized to matrix promotes cell growth. J Biol Chem 267:17606-17610.

Salpeter MM, Buonanno A, Eftimie R, Brenner HR, Pinset C, Mulle C, Benoit P, Changeux JP, Montarras D, Brehm P, Shepherd D, Froehner SC, Gordon H, Ralston E, Hall ZW, Lupa M, Rotundo R, Bertetta CF-V, Gomez AM, Barton F, Randall WR (1992) Regulation of molecules at the neuromuscular junction. In: Neuromuscular development and disease (Kelly AM, Blau HM, eds), pp 251-283. New York: Raven.

Seckl M, Rozengurt E (1993) Tyrphostin inhibits bombesin stimulation of tyrosine phosphorylation, c-fos expression, and DNA synthesis in Swiss 3T3 cells. J Biol Chem 268:9548-9554.

Sceds NW, Haffke SP, Hawkins RL, Krystosck A, McGuire PG, Verrall S (1992) Neuronal growth cones: battering rams or lasers? In: The nerve growth cone (Letourneau PC, Kater SB, Macagno ER, eds), pp 219-229. New York: Ravell.

Swenarchuk LE, Champaneria S, Anderson MJ (1990) Induction of a specialized muscle basal lamina at chimaeric synapses in culture. Development 110:51-61.

Vanderwinden JM, Mailleux P, Schiffmann SN, Vanderhaeghen JJ (1992) Cellular distribution of the new growth factor pleiotrophin (HB-GAM) mRNA in developing and adult rat tissues. Anat Embryol (Berl) 186:387-406.

Vigny M, Raulais D, Puzenat N, Duprez D, Hartmann MP, Jeanny JC, Courtois Y (1989) Identification of a new heparin-binding protein localized within chick basement membranes. Eur J Biochem 186 733-740.

Wallace BG, Qu Z, Huganir RL (1991) Agrin induces phosphorylation of the nicotinic acetylcholine receptor. Neuron 6:869-878.

Yanagishita M, Hascall VC (1992) Cell surface heparan sulfate proteoglycans. J Biol Chem 267:9451-9454.

Yayon A, Klagsbrun M, Esko JD, Leder P, Ornitz DM (1991) Cell surface, heparin-like molecules are required for binding of basic fibroblast growth factor to its high affinity receptor. Cell 64:841-848. 